\title{
THE
}

\section{Hemlock Woolly Adelgid in the Eastern United States: What Have We Learned?}

\author{
Evan L. Preisser \\ University of Rhode Island, preisser@uri.edu \\ Kelly L.F. Oten \\ Fred P. Hain
}

Follow this and additional works at: https://digitalcommons.uri.edu/bio_facpubs

The University of Rhode Island Faculty have made this article openly available.
Please let us know how Open Access to this research benefits you.

This is a pre-publication author manuscript of the final, published article.

Terms of Use

This article is made available under the terms and conditions applicable towards Open Access Policy Articles, as set forth in our Terms of Use.

\section{Citation/Publisher Attribution}

Preisser, Evan L.; Oten, Kelly L. F.; Hain, Fred P. (2014). "Hemlock Woolly Adelgid in the Eastern United States: What Have We Learned?" Southeastern Naturalist, 13(Special Issue 6), 1-15. doi: 10.1656/ 058.013.s604

Available at: 


\section{RUNNING HEAD: Adelgid overview}

TITLE: Hemlock Woolly Adelgid in the eastern United States: What have we learned?

$$
\text { Evan L. Preisser }{ }^{*} \text {, Kelly L. F. Oten }{ }^{2} \text { and Fred P. Hain }{ }^{3}
$$

${ }^{1}$ Department of Biological Sciences, University of Rhode Island, Kingston, RI 02881

${ }^{2}$ North Carolina Forest Service, Goldsboro, NC, 27530

${ }^{3}$ Department of Entomology, North Carolina State University, Raleigh, NC 27695

2

*Author to whom correspondence should be addressed: Evan Preisser, Department of Biological Sciences, University of Rhode Island, 9 E. Alumni Ave., Kingston, RI 02891 e-mail: preisser@uri.edu 
Abstract

23 Adelges tsugae Annand (Hemlock Woolly Adelgid) is a small piercing-sucking insect that

24 feeds on hemlock trees (Tsuga spp.). Native to Asia and the Pacific Northwest, the Hemlock

25 Woolly Adelgid is invasive in the eastern United States where it attacks Tsuga canadensis

26 (Eastern Hemlock) and T. caroliniana (Carolina Hemlock). It is currently found in 19 eastern

27 states and has caused extensive mortality to hemlock forests. The ecological and economic

28 impacts of this pest are significant, widespread, and often difficult to quantify. As the Hemlock

29 Woolly Adelgid continues to disperse throughout the range of Eastern and Carolina Hemlocks,

30 management techniques aimed at controlling it are being researched, implemented, and assessed.

31 This introductory paper provides an overview of the biology, life cycle, ecology, and history of

32 this pest in the eastern US as a foundation for this special issue.

Adelges tsugae Annand (Hemlock Woolly Adelgid) is a small ( $\sim 3 \mathrm{~mm}$ adult) piercing-

sucking insect that feeds on conifers in the genus Tsuga and Picea (Havill and Foottit 2007). The

37 population invasive to the eastern US is native to Japan (Havill et al. 2006). Although it has

38 minimal impact on its native host plants (McClure 1997), it has become a major pest in the

39 eastern US. In the eastern US, the adelgid feeds on T. canadensis Carrière (Eastern Hemlock)

40 and T. caroliniana Engelmann (Carolina Hemlock), two hemlock species that have little or no

41 defense against this insect (Montgomery et al. 2009). The resulting loss of hundreds of thousands

42 of trees from forests ranging from Georgia to Massachusetts has profoundly affected both local

43 communities and the associated ecosystems (Ellison et al. 2005). 
This special issue of Northeastern/Southeastern Naturalist explores the adelgid's impacts and

45 the challenges posed by its invasion. It contains articles surveying the wide range of adelgid-

46 related questions researchers are addressing throughout the invaded range. In the following

47 pages, we provide an overview of adelgid biology, its interactions with and impacts on other

48 species at the community and ecosystem level, and the current status of control efforts.

\section{Biogeography and history of the invasion}

50 Hemlock Woolly Adelgid was first described as a species in the early 1920's from

51 infestations on T. heterophylla Sargent (Western Hemlock) in the northwestern US (Annand

52 1924). The adelgid is genetically diverse throughout its native range, with different lineages

53 associated with particular regions and host plant species. Hemlock Woolly Adelgid in the

54 northwestern US is genetically different from the population native to Asia and the invasive

55 population in the eastern US, which originated from low-elevation populations infesting Tsuga

56 sieboldii Carrière (Southern Japanese Hemlock) in central Japan (Havill et al. 2006). Hemlock

57 Woolly Adelgid in the eastern US was first reported in the early 1950s near Richmond, Virginia

58 (Souto et al.1996). Although it was initially thought to be mainly a pest of ornamentals, by the

59 1980s the adelgid had also begun to harm forest hemlock. It is currently found in 19 eastern

60 states, ranging from northern Georgia to southern Maine (USFS 2012).

$61 \quad$ Life cycle

62 The Hemlock Woolly Adelgid has two generations per year in the invaded range (Figure 1).

63 In the early spring, first-instar nymphs of the spring generation (progrediens, plural

64 progredientes) emerge and seek out suitable feeding sites in the leaf cushion at the base of

65 hemlock needles (McClure 1989, Oten et al. 2012). These first-instar nymphs are known as

66 crawlers and can either move actively upon their natal host or be dispersed passively by wind, 
67 birds, deer, or humans (McClure 1990, Turner et al. 2011). Once the crawlers find an appropriate

68 feeding site, they settle permanently and use their feeding stylet bundle to probe and feed from

69 xylem ray parenchyma cells (Young et al. 1995). Adelgids go through four larval instars before

70 maturing into adults; because Hemlock Woolly Adelgid in the invaded range reproduces

71 asexually, each mature individual is theoretically capable of producing 20-30 summer-generation

72 (sistens, plural sistentes) offspring in early summer (McClure 1989, Paradis 2011). After the

73 summer-generation crawlers settle at the base of new-growth hemlock needles, they aestivate

74 until late fall, when they begin to feed. They feed throughout the winter, and each adult is

75 theoretically capable of producing 50-100 offspring the following spring (Paradis 2011).

76 While the spring generation is the same in the adelgid's native and invaded range, the

77 summer generation differs substantially between the two areas. Summer-generation eggs hatch

78 into either wingless asexual progrediens that feed on hemlock or winged sexually-reproducing

79 sexuparae that feed on Picea torano Carriere (Tiger Tail Spruce) in the native range (Sato 1999).

80 In the invaded range, however, there are no suitable spruce hosts and the sexuparae perish

81 without reproducing. As a result, HWA in the eastern US is obligately asexual and genetic

82 variability is limited. Despite this lack of genetic recombination, however, there is evidence for

83 adaptive genetic variation in cold tolerance in the invaded population (Butin et al. 2005).

$84 \quad$ Population ecology

85 Although mature adelgids can produce a large number of offspring, both juvenile and adult

86 adelgids also experience high mortality rates (McClure and Cheah 2002). The dispersing

87 crawlers are wingless, passively dispersed, and stand a high probability of ending up in

88 unsuitable habitat. Even under ideal conditions, early-instar mortality rates can approach $90 \%$

89 (Paradis 2011), and adults are susceptible to extreme heat in the summer and periods of intense 
90 cold in the winter (Trotter and Shields 2009). Because even low adelgid densities substantively

91 affect tree health, its survival is highly density-dependent (McClure 1991), with the previous

92 generation's density being the strongest predictor of survival (Paradis 2011). In the invaded

93 range, this density-dependent mortality is compounded by the fact that sexuparae production

94 increases in populations feeding on unhealthy or declining hosts. Both Eastern and Carolina

95 Hemlocks are, however, higher-quality host plants for the invasive adelgid population than many

96 hemlock species that have co-evolved with other lineages of the adelgid (Montgomery et al.

97 2009). This may provide one explanation for why the adelgid is so abundant in its novel range.

$98 \quad$ Community ecology

99 The Hemlock Woolly Adelgid has numerous predators in its native range ( Cota Vieira et al.

100 2013, Hakeem et al. 2011, McClure and Cheah 1999), but no predators native to the invaded

101 range appear capable of reducing adelgid densities sufficiently to consistently prevent hemlock

102 decline and death (Havill et al., 2012). As a result, its most important intraspecific interactions

103 likely involve those herbivores that co-occur on its host plant. Although Lambdina fiscellaria

104 Guenee (Hemlock Looper) has historically been considered a major hemlock pest (Trial and

105 Devine 1995), its densities appear to have declined in southern New England (E. Preisser,

106 personal observation). In this region, the most commonly co-occurring hemlock herbivore is

107 another invasive hemipteran, Fiorinia externa Ferris (Elongate Hemlock Scale) (Preisser et al.,

108 2008). This sessile armored scale feeds on the underside of hemlock needles, reproduces

109 sexually, and has one generation per year in the northeastern US and two generations in the

110 South (Abell and Van Driesche 2012, McClure 1978). Its dispersing crawler stage settles on

111 hemlock foliage in late spring, approximately one month after HWA crawlers have begun

112 feeding; because of this, the adelgid was predicted to competitively exclude the scale from 
113 hemlock (McClure 1997). In reality, however, both the range and population density of the scale

114 have increased sharply in adelgid-invaded areas of southern New England (Preisser et al. 2008).

115 Because the adelgid and elongate hemlock scale are both sessile and feed on different plant

116 structures, they interact via their impact on the shared host plant. This fact is important because

117 the two species have very different impacts on plant health; both experimental research (Miller-

118 Pierce et al. 2010, Miller-Pierce and Preisser 2012, Preisser and Elkinton 2008) and landscape

119 surveys (Preisser et al. 2008, 2011) have found that while the scale can reach higher densities

120 than the adelgid, the adelgid has a greater impact on plant health. Experimental work assessing

121 their interactions on hemlock branches found that each species decreased the other species'

122 density by $\sim 30 \%$ relative to when the species occur by themselves (Preisser and Elkinton 2008);

123 at the whole-tree level, however, intraspecific competition is only measurable when one species

124 arrives several years earlier than the other (Miller-Pierce and Preisser 2012). In such a scenario,

125 HWA densities are $40 \%$ lower when settling on trees previously infested with the scale; by

126 contrast, the prior presence of HWA does not significantly reduce scale densities (Miller-Pierce

127 and Preisser 2012). Most recently, experimental work found that HWA crawlers avoided settling

128 on EHS-infested branches, a finding supported by surveys showing that crawlers avoid settling at

129 the base of EHS-infested needles (Gomez et al. 2013). These findings suggest that EHS, despite

130 its apparent disadvantages, may actually be competitively dominant over HWA.

$131 \quad$ Interaction with hemlock

132 While HWA is capable of quickly killing hemlock trees (McClure 1991, Orwig et al. 2002),

133 the mechanism underlying such rapid HWA-mediated mortality has only recently begun to be

134 addressed. Following initial infestation, the tree declines in health. This period is marked by

135 needle drop, bud abortion, and inhibition of new growth (McClure 1991). A healthy hemlock can 
136 be killed in as little as four years, with many trees (especially in warmer climates) dying within

137 ten years of infestation (McClure 1987, 1991; see the following 'larger-scale effects' section,

138 below, for a more detailed description of adelgid-induced tree mortality). Some scientists

139 hypothesized that hemlocks died from resource depletion; large numbers of adelgids essentially

140 'starved' the tree of nutrients (McClure 1991). This explanation was challenged by work that

141 used scanning electron microscopy to identify the adelgid's precise feeding mode and cellular-

142 level impact (Young et al. 1995). Because these researchers found that adelgid feeding caused

143 relatively little cellular damage, they proposed that the adelgid's impact on tree health was better

144 explained by 'toxicity': fluids secreted by feeding adelgids, or the plant's response to the

145 feeding, had a disproportionately large impact on plant health. This explanation gained credence

146 with the large increase in elongate hemlock scale densities in southern New England; similarly-

147 sized to adelgids but more abundant (Preisser et al. 2008), these scales nonetheless had less

148 impact on hemlock growth and survival (Miller-Pierce et al. 2010, Miller-Pierce and Preisser

149 2012, Preisser and Elkinton 2008, Preisser et al. 2008, 2011).

150 The large amount of damage induced by HWA feeding appears linked to a hypersensitive

151 response in hemlock. The presence of HWA at the base of a needle causes extensive damage

152 (measured by the presence of hydrogen peroxidase) to the needle itself as well as to nearby 'new

153 growth' foliage that had not been colonized by HWA crawlers (Radville et al. 2011). The

154 hypersensitive response acts to isolate sessile herbivores by killing nearby tissue and starving the

155 feeding insect (Fernandes 1990, Fernandes and Negreiros 2001). In the case of HWA, the

156 hypersensitive response causes the induction of 'false growth rings' in infested stems that

157 interfere with solute transport and prevent the stems from obtaining the water necessary for

158 photosynthesis (Domec et al. 2013, Gonda-King et al. 2012). As a result, the plant may 
159 experience chronic water stress and eventually be unable to carry out photosynthesis (Domec et

160 al. 2013). Despite widespread cell death, induction of the hypersensitive response appears to

161 cause relatively little harm to feeding adelgids. On the contrary, HWA may themselves

162 biochemically manipulate the plant to induce this response. HWA possesses several enzymes

163 similar to those used by related insects to feed upon and influence their host plants (Oten 2011).

164 A detailed analysis of herbivore-mediated changes in hemlock amino acid concentrations found 165 that adelgids actually induced substantial increases in local nutrient levels (Gómez et al. 2012).

166 This manipulation may be similar to that occurring in galling insects, where sessile herbivores

167 manipulate plant physiology to build protective structures (i.e., galls) that serve as both food and 168 protection (Havill and Foottit 2007).

$169 \quad$ Larger-scale effects

170 The Hemlock Woolly Adelgid has killed so many hemlocks in the eastern US that the

171 International Union for Conservation of Nature (IUCN) recently labeled Eastern Hemlock 'near

172 threatened' and placed it on the Red List of Threatened Species (Farjon 2013). At the local level,

173 adelgid-induced hemlock mortality has substantially impacted many natural areas; Virginia's

174 Shenandoah National Park, for example, has lost $~ 90 \%$ of its mature hemlocks (Townsend and

175 Rieske-Kinney 2006). While noticeable hemlock mortality and decline continues, however, the

176 initial predictions of complete mortality of Eastern and Carolina Hemlock have not been realized

177 (Preisser et al. 2008). Especially in the northeastern US, a substantial number of infested trees

178 continue to persist: a long-term study in Delaware Water Gap National Park (located on the NJ-

179 PA border) found that $73 \%$ of hemlocks survived for longer than ten years (Eschtruth et al.,

180 2013). A recently-published analysis of Forest Inventory Analysis (FIA) data for 432 US

181 counties made a similar point (Trotter et al., 2013). It found little evidence for large-scale decline 
182 and a slight increase in median live hemlock basal area between 1985 and 2005, a fact it

183 attributed to the positive effects of reforestation and regeneration overwhelming the more recent

184 negative impacts of the adelgid.

185 Even if Eastern and Carolina Hemlock persist in eastern US ecosystems, the large losses 186 caused by adelgid infestation will substantially alter eastern forest ecosystems. Hemlocks are a

187 shade-tolerant 'foundation' species that shade and cool headwater streams that are home to trout 188 and a wide variety of aquatic invertebrates (reviewed in Ellison et al. 2005, Orwig and Foster 189 2000). They also assist in soil stabilization and controlling hydrologic regimes (Ford and Vose 190 2007). Over a nine-year period, adelgid-induced hemlock decline in the Delaware Water Gap 191 National Recreational Area (NJ) more than doubled understory light levels, increased vascular 192 plant cover nearly fourfold, and led to invasive plants colonizing 35\% of the surveyed plots 193 (Eschtruth et al. 2006). Hemlock stands are also critical habitat for a number of bird species

194 (Rabenold et al. 1998), and the loss of hemlocks can substantially affect invertebrate community 195 composition (Adkins and Rieske 2013, Dilling et al. 2007, Ingwell et al. 2012).

196 There are 274 cultivars of eastern hemlock, "making it one of the most cultured and 197 cultivated landscape tree species" (Quimby 1996, Swartley 1984) that is often used as a hedge 198 because of its response to shearing (Swartley 1984). It is also desired for its color, graceful habit, 199 and, until recently, its freedom from disease and insects. According to 1995 nursery inventories 200 in Tennessee and North Carolina, the value of eastern hemlock was approximately \$34 million 201 (J.R. Rhea, personal communication, cited in Bentz et al. 2002). The invasion of the adelgid has 202 reduced the importance of native hemlocks for ornamental use and will likely also affect the 203 more than 4 million cubic feet of timber produced in the region annually (Rhea 1995, Woodsen 204 2001). Land values also deteriorate as a result of adelgid infestations. A study in residential New 
205

206

207

208

209

210

211

212

213

214

215

216

217

218

219

220

221

222

223

224

225

226

227

Jersey found that $25-50 \%$ hemlock defoliation by the Hemlock Woolly Adelgid led nearby

property values to decline by an average of more than $\$ 7,000.00$ (Holmes et al. 2005). The future use of hemlocks as ornamentals relies in part on the ability to effectively manage the adelgid.

\section{Management methods}

Chemical control. Management of the Hemlock Woolly Adelgid is largely focused on

biological control and chemical control (McClure 2001, McClure and Cheah 1999, Montgomery

1999, also see Onken and Reardon 2011). Chemical control is currently the most effective

method and is widely used in ornamental and landscape settings, but it is generally impractical in

forest settings due to prohibitive costs and the potential environmental impacts of wide-scale use

(Cowles 2009, McClure 1992). The biggest limiting factor is cost. Trees must be treated

individually, often leading managers to target a series of 'high value' trees for treatment.

Because chemicals degrade over time, they must be periodically re-applied to ensure continued

control; in addition, there is the potential for non-target environmental impacts. The water-

solubility of systemic insecticides allows for rapid uptake and internal transportation of the

chemical throughout the tree, but also allows them to impact aquatic organisms in nearby water

bodies. Imidacloprid, for example, has been detected in water at sites with low soil organic

matter (U.S. EPA 2003). The mode of chemical application may also affect hemlock forest-

associated fauna. Soil injections of imidacloprid, for example, can cause significant declines in

the abundance and richness of soil-dwelling springtails and other non-target organisms

(Reynolds 2008). Forest applications may be limited due to geographical and logistical

constraints such as difficulties in bringing equipment into a forest (Cowles et al. 2006). Lastly,

pesticides are not a fail-proof method. In Joyce Kilmer Memorial Forest (NC), for example,

pesticide applications appear relatively ineffective in reducing adelgid populations (Bompey 
228 11/08/2010). Despite these concerns, research into chemical treatment options has decreased

229 their environmental impacts while increasing their efficacy (e.g., Cowles 2009). While chemicals

230 are often the best option in ornamental settings, they are generally impractical in forests as a

231 stand-alone management tool. Sustainable long-term adelgid management in forest settings will

232 likely require an integrated pest management program incorporating multiple management

233 techniques (Bentz et al. 2002, Del Tredici and Kitajima 2004, McClure and Cheah 1999).

234 Biological control. There appear to be no predators native to the invaded range capable of

235 consistently lowering adelgid densities sufficiently to prevent tree decline and death

236 (Montgomery and Lyon 1996, Wallace and Hain 2000, Havill et al. 2012). Researchers searching

237 for effective adelgid predators began to explore Asia and northwestern North America, the native

238 range of the Hemlock Woolly Adelgid, for organisms useful in a classical biological control

239 program. Since the 1990s, biological control has been a major focus of adelgid research and

240 management (McClure and Cheah 2002, Onken and Reardon 2011), an effort that expanded

241 considerably with the development of the Hemlock Woolly Adelgid Initiative in 2003. The

242 current program includes 28 federal and state agencies, 24 universities, seven institutions in

243 China and Japan, and numerous private industries (Onken and Reardon 2011).

244 Several beetle species have been released in hopes of controlling the Hemlock Woolly

245 Adelgid. The first was a coccinellid beetle, Sasajiscymnus tsugae Sasaji and McClure, that is

246 native to Japan and was first released in 1995 (Cheah 2008, 2011; Cheah and McClure 1998).

247 Since then, there have been more than two million S. tsugae released on more than 400 sites in

24816 states (Cheah 2011, Grant et al. 2010, Salom et al. 2008). It successfully reproduces and

249 disperses following release, and is capable of surviving extreme climatic events (Cheah 2011). 
Between 2004 and 2011, more than 61,000 individuals of Scymnus sinuanodulus Yu and

251 Yao, another coccinellid beetle native to China, have been released (Montgomery and Keena

252 2011). Because research suggests that this species is most climatically suited to the southern

253 portion of the hemlock range in the eastern US (Salom et al. 2008), most of these releases have

254 occurred in Georgia, North Carolina, and Tennessee. When released in these areas, the species

255 does not seem to require additional efforts to assist in its establishment (Montgomery and Keena

256 2011). Other beetles in the same genus have also been (S. ningshanensis Yu and Yao) or are

257 currently being pursued (S. coniferarum Crotch and S. camptodromus Yu and Liu) as biological

258 control agents. Native to western North America, the beetle S. coniferarum seems especially

259 promising since its feeding habits temporally complement that of Laricobius nigrinus Fender

260 (discussed in the next paragraph). Releases of $S$. coniferarum have begun, and research and

261 efficacy trials continue (Montgomery et al. 2011). Initial problems in rearing S. camptodromus

262 slowed this species' evaluation, but it is still being pursued because it diapauses at the same time

263 as the adelgid, has a broad geographic distribution, and is active during a critical period in the

264 adelgid life cycle (Montgomery and Keena 2011).

265 Laricobius nigrinus (Coleoptera: Derodontidae), a specialist adelgid predator native to

266 Oregon and Washington (Kohler et al. 2008), shows particular promise as a biological control

267 agent. Since its initial release in 2003, more than 380,000 beetles have been released throughout

268 the eastern US (Mausel et al. 2011, Salom et al. 2008). While its role as a biological control

269 agent seems promising given its field recovery success and ability to reduce adelgid populations,

270 it is hybridizing with a native beetle, L. rubidus LeConte (Klein et al. 2010), with unknown

271 consequences (Havill et al. 2012). This native beetle, which feeds primarily on Pineus strobi

272 Hartig (Pine Bark Adelgid), can be found feeding on Hemlock Woolly Adelgid in areas where 
273 white pine and hemlock co-occur (Montgomery and Lyon 1996, Wallace and Hain 2000). The

274 fact that L. nigrinus feeds exclusively on spring-generation eggs and nymphs (Kohler et al. 2008,

275 Zilahi-Balogh et al. 2002) suggests that it will be most effective as part of a suite of predators.

276 Another beetle in the same genus that is native to Japan, L. osakensis Montgomery and Shuyake,

277 is also being researched and released. This beetle is especially important since is native to the

278 region where the invasive lineage of the adelgid also occurs (Havill et al. 2006, Lamb et al.

279 2011). In 2012, 2000 L. osakensis were released (K. Mooneyham, pers. comm.) and research and 280 releases continue.

281 A number of other organisms also have potential as biological control agents. Leucopis spp.

282 flies (Diptera: Chamaemyiidae) prey on Hemlock Woolly Adelgid in northwestern North

283 America, but a lack of rearing methods and difficulty in species identification have slowed their

284 development as control agents (Ross et al. 2010). A fungal agent, Lecanicillium muscarium Zare

285 and Gams, is also under investigation (Salom et al. 2008). It is commercially available as

286 Mycotal, a biopesticide. Some formulations of this fungal agent, which has been approved for

287 use in the US and can already be found in eastern US hemlock forests, can reduce adelgid

288 populations by up to $75 \%$; research into the challenges posed by harsh abiotic conditions and the 289 need for mass deployment is ongoing (Costa 2010, 2011).

290 While biological control agents may help manage Hemlock Woolly Adelgid populations, the 291 high susceptibility of Eastern and Carolina Hemlock to the adelgid means that these agents must 292 cause extremely high adelgid mortality in order to be successful (McClure 1996). This level of 293 adelgid suppression will likely require a suite of predators (Cheah et al. 2004, Montgomery and 294 Lyon 1996); biological control agents may ultimately be most successful when incorporated into 295 a well-rounded integrated pest management program. 
Host-plant resistance. When grown in the eastern US and experimentally infested with the

297 Hemlock Woolly Adelgid, hemlock species native to Asia and the Pacific Northwest are tolerant 298 of and/or resistant to this pest (Bentz et al. 2002, 2007; Del Tredici and Kitajima 2004; Jetton et 299 al. 2008; Oten 2011). This suggests that host-plant factors may play a role, perhaps in concert 300 with natural enemies and the scattered distribution of hemlocks, in keeping adelgid densities low 301 in the native range (Montgomery and Lyon 1996).

302 Interspecific variation in hemlock resistance to the Hemlock Woolly Adelgid is well-

303 documented and continues to be pursued as a key component in a long-term, integrated approach 304 to adelgid management. Hybrid crosses between adelgid-resistant T. chinensis (Franch.) Pritzel 305 ex Diels and the adelgid-susceptible Carolina Hemlock produce progeny that are more adelgid306 resistant than Carolina Hemlocks (Montgomery et al. 2009). Similar hybridization attempts with 307 Eastern Hemlock have been unsuccessful (Bentz et al. 2002, Pooler et al. 2002), but advances in 308 hybridization methodology may assist in overcoming this obstacle.

309 There have also been reports of a few Eastern Hemlocks growing in heavily adelgid310 damaged regions that appear to have remained healthy and vigorous. Their existence and 311 continued vigor, despite coexisting with the Hemlock Woolly Adelgid for more than 20 years, 312 suggests the potential for some degree of adelgid resistance/tolerance in Eastern and Carolina 313 Hemlocks (Caswell et al. 2008). When cuttings from these putatively-resistant trees were grown 314 and evaluated in conjunction with cuttings from known adelgid-susceptible trees, the putatively315 resistant cuttings had lower adelgid settlement and higher adelgid mortality than did control 316 cuttings (Ingwell and Preisser 2011).

317 While the development of resistant hemlocks suitable for forest restoration in the eastern US 318 is a long process, initial investigations look somewhat promising. A long-term and sustainable 
319 approach to adelgid management will likely incorporate chemical control, biological control, and

320 host-plant resistance into an integrated management program.

\section{Conclusion}

322 The past decades have seen substantial progress towards a better understanding of adelgid

323 ecology and management. These accomplishments notwithstanding, we have yet to develop a

324 long-term and cost-effective management strategy for the Hemlock Woolly Adelgid. It is our

325 hope that the articles contained in this special feature move us closer to this goal, and to the

326 preservation of our native hemlock trees.

\section{Acknowledgements}

328 This manuscript benefitted greatly from the comments of three anonymous reviewers.

\section{Literature Cited}

Abell, K., and R. Van Driesche. 2012. Impact of latitude on synchrony of a scale (Fiorinia externa) (Hemiptera: Diaspididae) and its parasitoid (Encarsia citrina) (Hymenoptera: Aphelinidae) in the Eastern United States. Biological Control 63:339-347.

Adkins, J.K., and L.K. Rieske. 2013. Loss of a foundation forest species due to an exotic invader

Bentz, S.E., L. Riedel, M.R. Pooler, and A.M. Townsend. 2002. Hybridization and selfcompatibility in controlled pollinations of eastern North American and Asian hemlock Annand, P. 1924. A new species of Adelges (Hemiptera: Phylloxeridae). Pan-Pacific (Tsuga) species. Journal of Arboriculture 28:200-205. 
Proceedings: $17^{\text {th }}$ U.S. Department of Agriculture Interagency Research Forum on Gypsy Moth and other Invasive Species. US Forest Service, Morgantown WV.

344 Bompey, N. 11/08/2010. US Forest Service increases efforts to save hemlocks in Asheville area.

345 Page 2 Asheville Citizen Times, Asheville NC.

346 Butin, E., A.M. Porter, and J.S. Elkinton. 2005. Adaptation during biological invasions and the 347 case of Adelges tsugae. Evolutionary Ecology Research 87:887-900.

348 Caswell, T., R. Casagrande, B. Maynard, and E.L. Preisser. 2008. Production and evaluation of 349 eastern hemlocks potentially resistant to the hemlock woolly adelgid. Pp. 124-134, In B.

350 Onken and R.C. Reardon (Eds.). Fourth Symposium on Hemlock Woolly Adelgid in the $351 \quad$ Eastern United States. US Forest Service, Hartford, CT.

352 Cheah, C. 2008. The case for Sasajiscymnus tsugae: Biological control has helped save 353 Connecticut's hemlocks. Pp. 279-280, In B. Onken and R.C. Reardon (Eds.). Fourth 354 Symposium on Hemlock Woolly Adelgid in the Eastern United States. US Forest Service, 355 Hartford, CT.

356 Cheah, C. 2011. Sasajiscymnus (=Pseudoscymnus) tsugae, a ladybeetle from Japan. Pp. 43-52, 357 In B. Onken and R.C. Reardon (Eds.). Implementation and Status of Biological Control of 358 the Hemlock Woolly Adelgid. U.S. Forest Service, Morgantown, WV. 230 pp.

359 Cheah, C. and M. McClure. 1998. Life history and development of Pseudoscymnus tsugae 360 (Coleoptera: Coccinellidae), a new predator of the hemlock woolly adelgid (Homoptera: $361 \quad$ Adelgidae). Environmental Entomology 27:1531-1536.

362 Cheah, C., M.E. Montgomery, S.M. Salom, B.L. Parker, S.D. Costa, and M. Skinner. 2004. 363 Biological control of hemlock woolly adelgid. Reardon, R.C., and B. Onken (tech. coords.). 364 US Forest Service, Morgantown WV. 22 pp. 
365

366

367

368

369

370

371

372

373

374

375

376

377

378

379

380

381

382

383

384

385

386

387

Costa, S.D. 2010. Hemlock woolly adelgid suppression with aerial application of mycotal fungus in a microfactory formulation: can it work? Pp. 36-42, In B. Onken and R.C. Reardon (Eds.). Fifth Symposium on Hemlock Woolly Adelgid in the Eastern United States. US Forest Service, Asheville NC.

Costa, S.D. 2011. Insect-killing fungi for HWA management: Current status. Pp. 107-115, In B. Onken and R. Reardon (Eds.). Implementation and Status of Biological Control of the Hemlock Woolly Adelgid. U.S. Forest Service, Morgantown, WV.

Cota Vieira, L., A.S. Lamb, S. Shiyake, S. M. Salom, and L. T. Kok. 2013. Seasonal abundance and synchrony between Laricobius osakensis (Coleoptera: Derodontidae) and its prey, Adelges tsugae (Hemiptera: Adelgidae), in Japan. Annals of the Entomological Society of America 106:249-257.

Cowles, R., M.E. Montgomery, and C. Cheah. 2006. Activity and residues of imidacloprid applied to soil and tree trunks to control hemlock woolly adelgid (Hemiptera: Adelgidae) in forests. Journal of Economic Entomology 99:1258-1267.

Cowles, R. 2009. Optimizing dosage and preventing leaching of imidacloprid for management of hemlock woolly adelgid in forests. Forest Ecology and Management 257: 1026-1033.

Del Tredici, P. and A. Kitajima. 2004. Introduction and cultivation of Chinese hemlock (Tsuga chinensis) and its resistance to hemlock woolly adelgid (Adelges tsugae). Journal of Arboriculture 30:282-286.

Dilling, C., P. Lambdin, J. Grant, and L. Buck. 2007. Insect guild structure associated with eastern hemlock in the southern Appalachians. Environmental Entomology 36:1408-1414.

Domec, J.-C., L.N. Rivera, J.S. King, I. Peszlen, F.P. Hain, B. Smith, and J. Frampton. 2013. Hemlock woolly adelgid (Adelges tsugae) infestation affects water and carbon relations of 
eastern hemlock (Tsuga canadensis) and Carolina hemlock (Tsuga caroliniana). New Phytologist 199:452-463.

Ellison, A., M. Bank, B. Clinton, E. Colburn, K. Elliott, C. Ford, D. Foster, B. Kloeppel, J.

391 Knoepp, G. Lovett, J. Mohan, D. Orwig, N. Rodenhouse, W. Sobczak, K. Stinson, J. Stone,

392 C. Swan, J. Thompson, B. Von Holle, and J. Webster. 2005. Loss of foundation species:

393 consequences for the structure and dynamics of forested ecosystems. Frontiers in Ecology

394 and the Environment 3:479-486.

395 Eschtruth, A.K., N. Cleavitt, J.J. Battles, R.A. Evans, and T. Fahey. 2006. Vegetation dynamics

396 in declining eastern hemlock stands: 9 years of forest response to hemlock woolly adelgid

397 infestation. Canadian Journal of Forest Research 36:1435-1450.

398 Eschtruth, A.K., R.A. Evans, and J.J. Battles. 2013. Patterns and predictors of survival in Tsuga

399 canadensis populations infested by the exotic pest Adelges tsugae: 20 years of monitoring.

$400 \quad$ Forest Ecology and Management 305:195-203.

401 Farjon, A. 2013. Tsuga canadensis. In: IUCN 2013. IUCN Red List of Threatened Species.

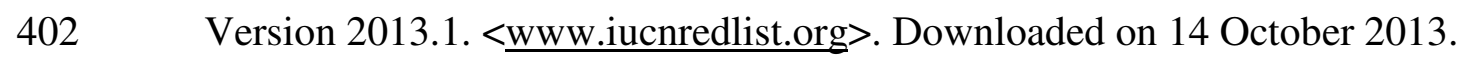

403 Fernandes, G. 1990. Hypersensitivity: a neglected plant resistance mechanism against insect

404 herbivores. Environmental Entomology 19:1173-1182.

405 Fernandes, G., and D. Negreiros. 2001. The occurrence and effectiveness of hypersensitive

406 reaction against galling herbivores across host taxa. Ecological Entomology 26:46-55.

407 Ford, C.R., and J.M. Vose. 2007. Tsuga canadensis (L.) Carr. mortality will impact hydrological

$408 \quad$ processes in southern Appalachian forest ecosystems. Ecological Applications 17: 1156-

$409 \quad 1167$.


410 Gomez, S., L. Gonda-King, C.M. Orians, and E.L. Preisser. 2014. Competitor avoidance drives

411 within-host feeding site selection in a passively-dispersed herbivore. Ecological Entomology

$412 \quad 39: 10-16$.

413 Gómez, S., C.M. Orians, and E.L. Preisser. 2012. Exotic herbivores on a shared native host:

414 tissue quality after individual, simultaneous, and sequential attack. Oecologia 169:1015-

4151024.

416 Gonda-King, L., L. Radville, and E.L. Preisser. 2012. False ring formation in eastern hemlock

417 branches: impacts of hemlock woolly adelgid and elongate hemlock scale. Environmental

$418 \quad$ Entomology 41:523-531.

419 Grant, J., A. Hakeem, J.R. Rhea, G. Wiggins, P. Lambdin, and G. Taylor. 2010. Recovery and

420 establishment of introduced predators of hemlock woolly adelgid in the southern

421 Appalachians. Pp. 21-23, In B. Onken and R.C. Reardon (Eds.). Fifth Symposium on

422 Hemlock Woolly Adelgid in the Eastern United States. US Forest Service, Asheville NC.

423 Hakeem, A., J. Grant, G. Wiggins, P. Lambdin, and J.R. Rhea. 2011. Establishment and

424 coexistence of two predators, Laricobius nigrinus and Sasajiscymnus tsugae, introduced

425 against hemlock woolly adelgid on eastern hemlock. Biocontrol Science and Technology

$426 \quad 21: 687-691$.

427 Havill, N., G. Davis, D.L. Mausel, J. Klein, R. McDonald, C. Jones, M. Fischer, S.M. Salom, 428 and A. Caccone. 2012. Hybridization between a native and introduced predator of Adelgidae:

429 An unintended result of classical biological control. Biological Control 63:359-369.

430 Havill, N. and R. Foottit. 2007. Biology and evolution of Adelgidae. Annual Review of

$431 \quad$ Entomology 52:325-349. 
432 Havill, N., M.E. Montgomery, G. Yu, S. Shiyake, and A. Caccone. 2006. Mitochondrial DNA

433 from hemlock woolly adelgid (Hemiptera: Adelgidae) suggests cryptic speciation and

434 pinpoints the source of the introduction to eastern North America. Annals of the

435 Entomological Society of America 99:195-203.

436 Holmes, T., E. Murphy, and D. Royle. 2005. The economic impacts of hemlock woolly adelgid

437 on residential landscape values: Sparta, New Jersey case study. Pp. 15-24, In B. Onken and

438 R.C. Reardon (Eds.). Third Symposium on the Hemlock Woolly Adelgid in the Eastern

439 United States. US Forest Service, Asheville, NC.

440 Ingwell, L.L., and E.L. Preisser. 2011. Using citizen science programs to identify host resistance

441 in pest-invaded forests. Conservation Biology 25:182-188.

442 Ingwell, L., M. Miller-Pierce, R.T. Trotter III, and E.L. Preisser. 2012. Vegetation and

443 invertebrate community response to eastern hemlock decline in southern New England.

$444 \quad$ Northeastern Naturalist 19:541-558.

445 Jetton, R.M., F.P. Hain, W.S. Dvorak, and J. Frampton. 2008. Infestation rate of hemlock woolly

446 adelgid (Hemiptera: Adelgidae) among three North American hemlock (Tsuga) species

447 following artificial inoculation. Journal of Entomological Science 43:438-442.

448 Klein, J.L., A. Caccone, and N. Havill. 2010. Polymorphic microsatellite loci for Laricobius

449 nigrinus and L. rubidus (Coleoptera: Derodontidae), predators of the hemlock woolly

$450 \quad$ adelgid. Molecular Ecology Resources 10: 751-754.

451 Kohler, G.R., V.L. Stiefel, K.F. Wallin, and D.W. Ross. 2008. Predators associated with the

452 hemlock woolly adelgid (Hemiptera: Adelgidae) in the Pacific Northwest. Environmental

453 Entomology 37: 494-505. 
454 Lamb, A., M.E. Montgomery, L. Cota Vieira, S. Shiyake, and S.M. Salom. 2011. Laricobius

455 osakensis, a hemlock woolly adelgid predator from Japan. Pp. 90-96, In B. Onken and R.C.

456 Reardon (Eds.). Implementation and Status of Biological Control of the Hemlock Woolly

457 Adelgid. U.S. Forest Service, Publication FHTET-2011-04, Morgantown, WV. 230 pp.

458 Mausel, D.L., G.A. Davis, A.B. Lamb, G.M.G. Zilahi-Balogh, L.T. Kok, and S.M. Salom. 2011.

459 Laricobius nigrinus Fender (Coleoptera: Derodontidae). Pp. 77-89, In B. Onken and R.C.

460 Reardon (Eds.). Implementation and Status of Biological Control of the Hemlock Woolly

461 Adelgid. U.S. Forest Service, Publication FHTET-2011-04, Morgantown, WV. 230 pp.

462 McClure, M.S. 1978. Seasonal development of Fiorinia externa, Tsugaspidiotus tsugae

463 (Homoptera: Diaspididae), and their parasite, Aspidiotiphagus citrinus (Hymenoptera:

464 Aphelinidae): Importance of parasite-host synchronism to the population dynamics of two

465 scale pests of hemlock. Environmental Entomology 7:863-870.

466 McClure, M.S. 1987. Biology and control of hemlock woolly adelgid. Bulletin of the

467 Connecticut Agricultural Experiment Station 851.

468 McClure, M.S. 1989. Evidence of a polymorphic life cycle in the hemlock woolly adelgid

469 Adelges tsugae (Homoptera: Adelgidae). Annals of the Entomological Society of America $470 \quad 82: 50-54$

471 McClure, M.S. 1990. Role of wind, birds, deer, and humans in the dispersal of hemlock woolly 472 adelgid (Homoptera: Adelgidae). Environmental Entomology 19:36-43.

473 McClure, M.S. 1991. Density-dependent feedback and population cycles in Adelges tsugae

474 (Homoptera: Adelgidae) on Tsuga canadensis. Environmental Entomology 20:258-264. 
475 McClure, M.S. 1992. Effect of implanted and injected pesticides and fertilizers on the survival of 476 Adelges tsugae (Homoptera: Adelgidae) and on the growth of Tsuga canadensis. Journal of $477 \quad$ Economic Entomology 85:468-472.

478 McClure, M.S. 1996. Biology of Adelges tsugae and its potential for spread in the northeastern 479 United States. Pp. 16-25, In S.M. Salom, T. Tigner, and R.C. Reardon (Eds.). First Hemlock 480 Woolly Adelgid Review. US Forest Service, Morgantown, WV.

481 McClure, M.S. 1997. Biological control in native and introduced habitats: Lessons learned from 482 the sap-feeding guilds on hemlock and pine. Pp 31-52, In D. Andow, D. Ragsdale, and R. 483 Nyvall, editors. Ecological Interactions and Biological Control. Westview Press, Boulder $484 \quad$ CO.

485 McClure, M.S. 2001. Biological control of hemlock woolly adelgid in the eastern United States. 486 FHTET-2000-08. USDA Forest Service, Forest Health Technology Enterprise Team, 487 Morgantown, WV. 10 pp.

488 McClure, M.S., and C. Cheah. 1999. Reshaping the ecology of invading populations of hemlock 489 woolly adelgid, Adelges tsugae (Homoptera: Adelgidae), in Eastern North America.

$490 \quad$ Biological Invasions 1:241-254.

491 McClure, M.S., and C. Cheah. 2002. Important mortality factors in the life cycle of hemlock 492 woolly adelgid Adelges tsugae in the northeastern United States. Pp. 13-22, In Symposium 493 on the Hemlock Woolly Adelgid in Eastern North America. US Forest Service, New $494 \quad$ Brunswick, NJ.

495 Miller-Pierce, M., D.A. Orwig, and E.L. Preisser. 2010. Effects of hemlock woolly adelgid and 496 elongate hemlock scale on eastern hemlock growth and foliar chemistry. Environmental $497 \quad$ Entomology 39:513-519. 
498 Miller-Pierce, M. and E.L. Preisser. 2012. Asymmetric priority effects influence the success of

499 invasive forest insects. Ecological Entomology 37:350-358.

500 Montgomery, M.E. 1999. Woolly adelgids in the southern Appalachians: Why they are harmful 501 and prospects for control. Pp. 47-57, In P. Gibson and C.R. Parker (Eds.). Proceedings of the 502 Southern Appalachian Biological Control Initiative Workshop, 26-27 September 1996.

503 FHTET-98-14. USDA Forest Service, Forest Health Technology Enterprise Team, 504 Morgantown, WV.

505 Montgomery, M.E., and M.A. Keena. 2011. Scymnus (Neopullus) lady beetles from China. Pp.

506 53-76, In B. Onken and R.C. Reardon (Eds.). Implementation and Status of Biological

507 Control of the Hemlock Woolly Adelgid. U.S. Forest Service, Publication FHTET-2011-04, 508 Morgantown, WV. 230 pp.

509 Montgomery, M.E., and S.M. Lyon. 1996. Natural enemies of adelgids in North America: Their 510 prospect for biological control of Adelges tsugae (Homoptera: Adelgidae). Pp. 89-102, In

511 S.M. Salom, T.C. Tigner, and R.C. Reardon (Eds.). Proceedings of the first Hemlock Woolly 512 Adelgid review; 1995 October 12; Charlottesville, VA. FHTET 96-10. Morgantown, WV:

513 U.S. Department of Agriculture, Forest Service, Forest Health Technology Enterprise Team.

514 Montgomery, M., S. Bentz, and R. Olsen. 2009. Evaluation of hemlock (Tsuga) species and 515 hybrids for resistance to Adelges tsugae (Hemiptera: Adelgidae) using artificial infestation. $516 \quad$ Journal of Economic Entomology 102:1247-1254.

517 Montgomery, M.E., T.J. McAvoy, and S.M. Salom. 2011. Other species considered. Pp. 116518 122, In B. Onken and R.C. Reardon (Eds.). Implementation and Status of Biological Control 519 of the Hemlock Woolly Adelgid. U.S. Forest Service, Publication FHTET-2011-04, $520 \quad$ Morgantown, WV. 230 pp. 
521 Mooneyham, K. 2013. Personal communication. 16 October 2013.

522 Onken, B., and R.C. Reardon (Eds.). 2011. Implementation and Status of Biological Control of 523 the Hemlock Woolly Adelgid. USDA FHTET-2011-04. 230 pp.

524 Orwig, D.A., and D. Foster. 2000. Stand, landscape, and ecosystem analyses of hemlock woolly 525 adelgid outbreaks in southern New England: an overview. Pp. 123-125, In Symposium on 526 Sustainable Management of Hemlock Ecosystems in Eastern North America. US Forest 527 Service, Newtown Square, PA.

528 Orwig, D.A., D. Foster, and D.L. Mausel. 2002. Landscape patterns of hemlock decline in New 529 England due to the introduced hemlock woolly adelgid. Journal of Biogeography 29:1475$530 \quad 1487$.

531 Oten, K.L.F. 2011. Host-plant selection by the hemlock woolly adelgid, Adelges tsugae Annand:

532 Sensory systems and feeding behavior in relation to physical and chemical host-plant 533 characteristics. Ph.D. Dissertation. North Carolina State University, Raleigh, N.C.

534 Oten, K.L.F., G.R. Bauchan, J. Frampton, and F.P. Hain. 2012. Biophysical characteristics of the 535 stem and petiole surface of six hemlock (Tsuga) species and a hybrid: implications for 536 resistance to Adelges tsugae. Botany 90:1170-1178.

537 Paradis, A. 2011. Population dynamics of the hemlock woolly adelgid (Hemiptera: Adelgidae).

538 Ph.D. Dissertation. University of Massachusetts, Amherst, Amherst.

539 Pooler, M.R., L.G.H. Riedel, S.E. Bentz, and A.M. Townsend. 2002. Molecular markers used to

540 verify interspecific hybridizations between hemlock (Tsuga) species. Journal of the

541 American Society for Horticultural Science 127(4):623-627.

542 Preisser, E.L., and J.S. Elkinton. 2008. Exploitative competition between invasive herbivores 543 benefits a native host plant. Ecology 89:2671-2677. 
544 Preisser, E.L., A. Lodge, D.A. Orwig, and J.S. Elkinton. 2008. Range expansion and population

545 dynamics of co-occurring invasive herbivores. Biological Invasions 10:201-213.

546 Preisser, E.L., M. Miller-Pierce, J. Vansant, and D.A. Orwig. 2011. Eastern hemlock (Tsuga

547 canadensis) regeneration in the presence of hemlock woolly adelgid (Adelges tsugae) and

548 elongate hemlock scale (Fiorinia externa). Canadian Journal of Forest Research 41:2433-

5492439.

550 Quimby, J.W. 1996. Value and importance of hemlock ecosystems in the eastern United States.

551 Pp. 1-8, In S.M. Salom, T. Tigner, and R.C. Reardon (Eds.). First Hemlock Woolly Adelgid

552 Review. US Forest Service, Morgantown, WV.

553 Rabenold, K.N., P.T. Fauth, B.W. Goodner, J.A. Sadowski, and P.G. Parker. 1998. Response of

554 avian communities to disturbance by an exotic insect in spruce-fir forests of the southern

$555 \quad$ Appalachians. Conservation Biology 12:177-189.

556 Radville, L., A. Chaves, and E.L. Preisser. 2011. Variation in plant defense against invasive

557 herbivores: evidence for a hypersensitive response in eastern hemlocks (Tsuga canadensis).

$558 \quad$ Journal of Chemical Ecology 37:592-597.

559 Reynolds, W.N. 2008. Imidacloprid insecticide treatments for hemlock woolly adelgid, Adelges

560 tsugae Annand (Hemiptera: Adelgidae), affect a non-target soil arthropod community

$561 \quad$ surrounding eastern hemlock, Tsuga canadensis Carriere. University of Tennessee,

$562 \quad$ Knoxville.

563 Rhea, J.R. 1995. Economic and environmental impacts of the hemlock woolly adelgid (Adelges

564 tsugae) on the hemlock resources of Eastern North America. In Proceedings: International

565 Union of Forest Research Organizations, XX World Congress. 
566 Ross, D., S. Grubin, G. Kohler, and K.M. Wallin. 2010. Evaluation of Leucopis species (Diptera:

567 Chamaemyiidae) from the PNW as potential biological control for the hemlock woolly

568 adelgid. Pp. 32, In B. Onken and R.C. Reardon (Eds.). Fifth Symposium on Hemlock Woolly

569 Adelgid in the Eastern United States. US Forest Service, Asheville NC.

570 Salom, S.M., L.T. Kok, A.B. Lamb, C. Jubb, and B. Onken. 2008. Biological control of hemlock

571 woolly adelgid: What is it going to take to make it work? Pp. 11-18, In B. Onken and R.C.

572 Reardon (Eds.). Fourth Symposium on Hemlock Woolly Adelgid in the Eastern United

573 States. US Forest Service, Hartford, CT.

574 Sato, S. 1999. Galls on tiger-tail spruce made by Aphrastasia tsugae at Mt. Tsurugi. Gensei 73:157526.

576 Souto, D., T. Luther, and B. Chianese. 1996. Past and current status of hemlock woolly adelgid 577 in eastern and Carolina hemlock stands. Pp. 9-15, In S.M. Salom, T. Tigner, and R. Reardon 578 (Eds.). First Hemlock Woolly Adelgid Review. US Forest Service, Morgantown, WV.

579 Swartley, J.C. 1984. The Cultivated Hemlocks. Timber Press, Portland, OR.

580 Townsend, L. and L. Rieske-Kinney. 2006. ENTFACT-452: Meeting the threat of the hemlock $581 \quad$ woolly adelgid. Pp. 1-8. UK Cooperative Extension Service, Lexington.

582 Trial, H. and M. Devine. 1995. The impact of the hemlock loopers, Lambdina fiscellaria

583 (Guenée) and L. Athasaria (Walker) on eastern hemlock and balsam fir in New England.

$584 \quad$ Bureau of Forestry, Orono ME.

585 Trotter III, R. T. and K. Shields. 2009. Variation in winter survival of the invasive hemlock 586 woolly adelgid (Hemiptera: Adelgidae) across the Eastern United States. Environmental $587 \quad$ Entomology 38:577-587. 
588 Trotter III, R.T., R.S. Morin, S.N. Oswalt, and A.M. Liebhold. 2013. Changes in the regional 589 abundance of hemlock associated with the invasion of hemlock woolly adelgid. Biological $590 \quad$ Invasions (2013): 1-13.

591 Turner, J., M. Fitzpatrick, and E.L. Preisser. 2011. Simulating the dispersal of hemlock woolly 592 adelgid in the temperate forest understory. Entomologia Experimentalis et Applicata $593 \quad 141: 216-223$.

594 U.S. Environmental Protection Agency, 2003. Imidacloprid; Pesticide tolerances. Fed. Regist. 595 68, 35303-35315 [online].http://www.epa.gov/fedrgstr/EPA-PEST/2003/June/Day596 13/p14880.htm. U.S. EPA, Washington, DC.

597 USFS. 2012. Forest Health Protection - Hemlock Woolly Adelgid Distribution Map. Forest $598 \quad$ Health Protection Service, Newtown Square PA.

599 Wallace, M. and F.P. Hain. 2000. Field surveys and evaluation of native and established

600 predators of the hemlock woolly adelgid (Homoptera: Adelgidae) in the southeastern United $601 \quad$ States. Environmental Entomology 29:638-644.

602 Woodsen, M.M. 2001. Forest invaders-insects that invade hemlock trees. American Forests 4: $603 \quad 12-13$.

604 Young, R., K. Shields, and G. Berlyn. 1995. Hemlock woolly adelgid (Homoptera: Adelgidae): 605 stylet bundle insertion and feeding sites. Annals of the Entomological Society of America $606 \quad 88: 827-835$

607 Zilahi-Balogh, G.M.G., L.T. Kok, and S.M. Salom. 2002. Host specificity of Laricobius nigrinus 608 Fender (Coleoptera: Derodontidae), a potential biological control agent of the hemlock $609 \quad$ woolly adelgid, Adelges tsugae Annand (Homoptera: Adelgidae). Biological Control 24: $610 \quad 192-198$. 
611 Figure 1: Hemlock Woolly Adelgid life cycle. In Japan, the adelgid alternates between Hemlock

612 and Tigertail Spruce. Tigertail Spruce supports a sexual generation and gall formation. In the

613 eastern United States there are only two generations on Hemlock, because winged migrants do

614 not find suitable spruce species on which to complete the entire life cycle. The letters ' $\mathrm{A}$ ' and ' $\mathrm{B}$ '

615 refer to where the cycle begins again. Vince D'Amico and Nathan Havill created the artwork for

616 this figure.

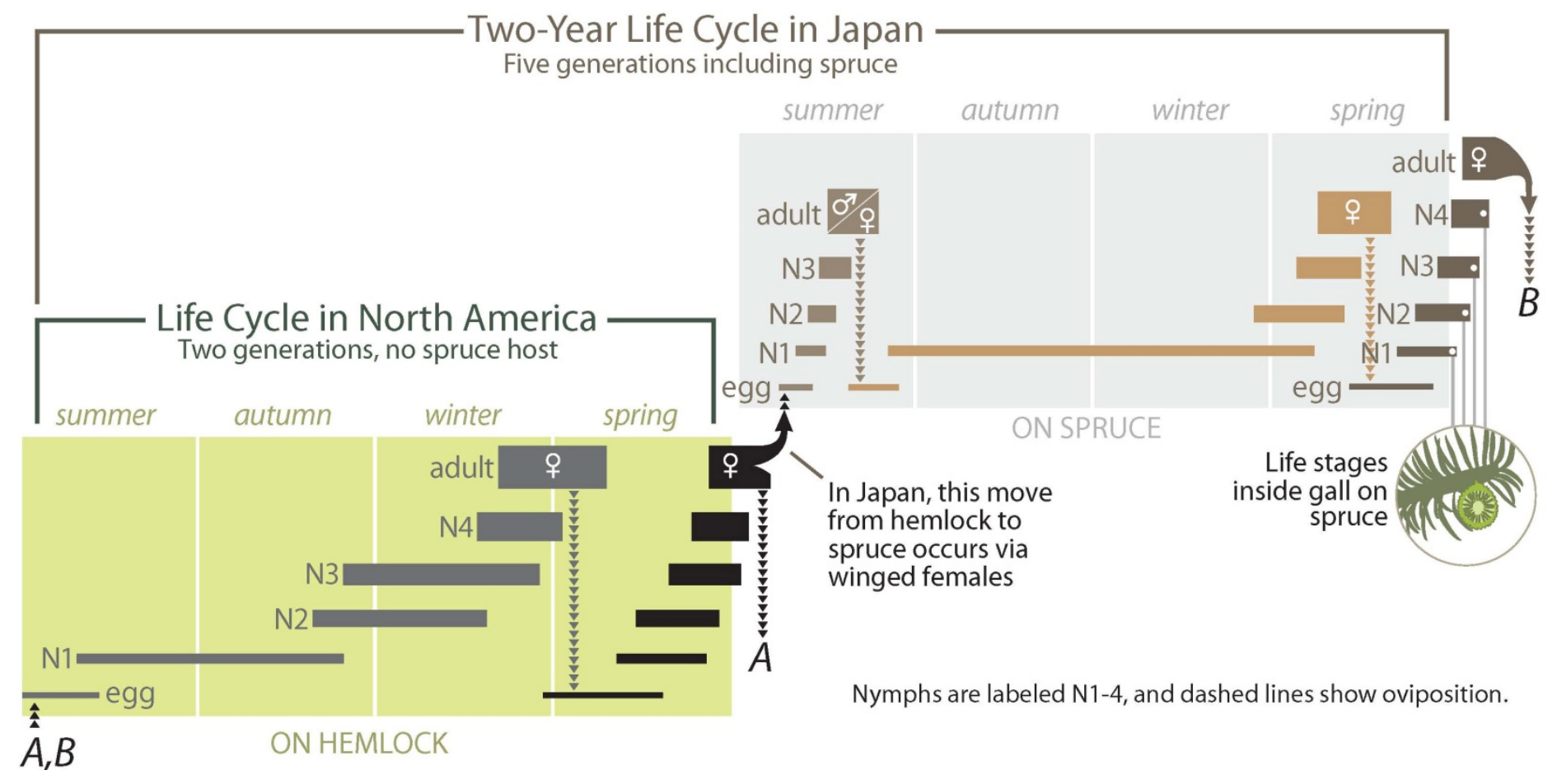

